\title{
Reporting Systems in Public Administration: The New Approach for Austrian Universities
}

UDK: 378(94)

\author{
Michaela Schaffhauser-Linzatti \\ University of Vienna, School of Business, Economics, and Computer Science \\ schaffhauser_linzatti@hotmail.com
}

\begin{abstract}
Together with the reorganisation of public administration, reporting on public performances is steadily becoming more transparency and process efficiency orientated. Various levels of reporting are being acquired, depending on the stakeholders concerned, comprising internal, inter-bureaucratic, and external information systems. Taking Austrian universities as an example, this article shows the advantages and pitfalls present when such reporting systems are "borrowed" from private applications without adapting them to public necessities. It focuses on the Austrian university intellectual capital statement as one of the most important reports using intangible values in the light of theoretical criteria and practical experience.
\end{abstract}

Key words: Public administration, university, public performance, reporting system, non-monetary indicators

\section{Introduction}

Public sector organisations in most European countries are undergoing continual and rigorous structural change. After privatising large parts of public service industries not only in Central and Eastern Europe but in most countries of the European Union (see Schaffhauser-Linzatti 2000), the concept of Public-Private Partnership has been applied to many public service tasks that can be partially performed by private undertakings (see e.g. Setnikar-Cankar , 2002, 2003, 2004). However, the hardcore of public administration, which cannot be outsourced to private institutions, also faces rigorous reorganisation, especially those public institutions that are, whilst nominally autonomous, still subordinate to a federal ministry, e.g., universities. (The following article focuses on such "outlays" in socalled public entities). Increasing public deficits and growing demands by the broader public for efficient use of public budgetary revenues have brought about 


\section{Michaela Schaffhauser-Linzatti \\ Reporting Systems in Public Administration}

a new public management oriented towards making use of private enterprise. Consequently, not only the process of service provision has to be restructured but also reporting on its results.

Alongside ongoing public discussion on the subject new reporting systems are being developed and implemented. Contrary to popular belief, it is not possible to duplicate reporting systems that have been successfully implemented in private firms, as public administration is not market-oriented but mostly fulfils non-profit-oriented tasks. Hence public reporting systems should not concentrate on presenting financial results but on informing on the achievement or underachievement of public tasks using mainly non-monetary indicators. In the following, reports will be defined as instruments that support information processing and publishing of achievements.

In general, public administration reports should comprise three main focuses:

1. the internal focus, which must concentrate on the efficient use of allocated public resources, requiring the implementation of managerial and financial accounting systems as well as comprehensive information management systems for specific administrative procedures;

2. the inter-bureaucratic focus, which must concentrate on the information flow between a federal ministry and its public entities where in most cases the federal ministry allocates resources according to politically determined distribution factors. If a more performance-based resource allocation is introduced, the reporting systems must concentrate on targets that are defined in advance on the actual degree of the achievement of these targets and on a future outlook;

3. the external focus, which must concentrate on informing the broader public and other political decision makers on the achievements of the public entities. This information should not be identical to that provided by the inter-bureaucratic focus and presented in a more marketable and interpretable way.

Each of the three report categories have different requirements and need different specifications in regard to structure, technical equipment, and presentation in order to meet the expectations of the interested parties and the objectives these reports are designed to help realise.

The report classification presented here is intended to be generally applicable for all kinds of public entities. Austrian universities shall serve as an example. The categorisation of their reports in this paper, however, does not follow the classification scheme formally suggested by Schaffhauser-Linzatti (2004) to the Federal Ministry of Education, Science and Culture (hereinafter: Federal Ministry) specifically for Austrian universities to support a quick implementation with little 
overlaps within the complicated report structures. Nevertheless, a new classification as far as this paper is concerned does not conflict with any legal standardisation, as legal prescriptions do not include any classification of the demanded reports. On the contrary, it supports the general applicability of the approach discussed above.

The University Organisation and Studies Act (Universities Act 2002), University Organisation Amendment Act and Universities of the Arts Organisation Amendment Act, no. 120/2002 / 9 August 2002 (UG 2002) ${ }^{\mathbf{1}}$ applying to all state universities from 1 January 2004 have adopted the new Austrian university reports. In compliance with the amendment to the civil servant law (Dienstrechtsnovelle 2001), this legislation strives at restructuring the educational and legal framework of universities. Under the old law universities directly depended on the Federal Ministry, which determined the curricula or - to a certain degree university staffing. The universities were allocated a detailed budget that was structured according to precisely defined, inflexible criteria. Now, they are granted full autonomy from the Federal Ministry. The public budgets are also put on a new, more performance-oriented basis. Hence new reporting instruments have become necessary to broaden the information flow between the universities and the Federal Ministry. These instruments again require comprehensive internal information systems. Furthermore, transparency and communication to the broader public is to be intensified.

This paper first presents the Austrian university reports according to the classification scheme developed above. Because of the expected future importance and uniqueness of the intellectual capital statement, it then aims at initiating the discussion about intellectual capital statements for universities on an international basis.

\section{Austrian university reports}

\section{I) Internal focus}

Art. 16 (1) obliges universities to introduce "an accounting system, including income and expenditure accounting, and a reporting system ...". These internal reports can be structured individually. Contrary to the initial intention, they do not exclusively serve the internal support, management, and controlling of each university but provide the information basis for most of the inter-bureaucratic and external reports. The imprecise formulation of Art.16 (1) means there is an implicit duty to install an external financial as well as an internal managerial accounting system under the responsibility of the rectorate. An example for information systems

1 All articles refer to the UG 2002, except stated otherwise. 


\section{Michaela Schaffhauser-Linzatti \\ Reporting Systems in Public Administration}

that are "appropriate to [the university's] duties" is the students administration system, UNIVIS, of the University of Vienna. It represents a typical interface to external information systems, as part of UNIVIS can also be used by students.

\section{II) Inter-bureaucratic focus}

The inter-bureaucratic reports between the university and the Federal Ministry are the most important but also the most costly and time-consuming. They have to be prepared by the rectorate and the rector in accordance with UG 2002 and the corresponding orders of the Federal Ministry. They are sent to the Federal Ministry after authorisation of the University Council. The main contents have to be published to the broader public in printed form and on the internet. Although the information transferred to the Federal Ministry is standardised it will probably be presented in a different, more marketable and interpretable form for external stakeholders. Hence, they also comprise an external focus, which has to be taken into consideration from the first moment of conceptualising.

\section{Ila) Performance report}

Each university "shall submit performance reports based on the performance agreements to the Minister by 30 April each year" (Art. 13 (5)). The performance agreement[s] is a contract by public law between each university and the Federal Government limited in duration by the law to periods of three years (Art. 13 (1)). It determines the universities' duties and rights and mainly serves as a basis for negotiation over each university's basic and formula-based budget (Art. 12). The performance report has to be published annually together with the financial statement and the auditor's report (Art. 16 (4)). It will contain the results of evaluations and a description of the qualitative and quantitative development of the university in relation to the aims of the performance agreement (Seboek 2002, 60, Art. 10 (12) RV 2002). Furthermore the performance report has to include "forecasts of the performance outcomes and the financial performance of the respective university in the third year" (Art. 13 (5)). Thus it summarises all of a university's activities during one year and represents the basis for the university report according to Art. 11. Until the first performance agreement period 2007-2009, the performance report is substituted by an activities' report (Art. 121 (16)).

\section{Ilb) Intellectual capital statement}

Each university "shall submit an intellectual capital statement for the last calendar year to the Minister by 30 April each year" (Art. 13 (6)). The intellectual capital statement is designed as an inventory of the existing intellectual capital within the university and serves as an important basis for the university's budgetary reimbursement (Seboek 2002, 60). 
Some regulations appertaining to the intellectual capital statement are contradictory. First, the intellectual capital statement is, on the one hand, part of the performance report (Art. 12 (8), $13(4),(6))$, on the other hand it represents an independent report (Art. 20 (6(3)), 21 (1(9)), 22 (1(15))). Then, the UG 2002 does not state in which year the intellectual capital statement has to be published first and the Federal Ministry will require the first report to be published in 2006 for the year 2005 already. Finally, the intellectual capital statement has to be submitted to the University Council by 30 April each year analogous to the performance report (Art. 16 (4)), although it is supposed to have already been submitted to the Federal Ministry by 30 April (Art. $13(6))$.

\section{IIc) Evaluation report}

The subject of the evaluation, as the principle instrument of quality assurance, are all the university's duties and the entire spectrum of its services (Art. 14 (1),(2)). The UG 2002 especially emphasises the student evaluation of teaching (Art. $13(2(1 \mathrm{c})), 14(8))$ and the mandatory evaluation of all Art. 94 (2) employees (Art.14 (7) in accordance with Dienstrechtsnovelle 2001). Internal evaluations can be provided on a voluntary, individual basis in accordance with the university's statutes (Art. 14 (4)); any obligation to publish is not explicitly stated in the UG 2002. External evaluations shall take place at the instigation of the rectorate, the University Council, or the Federal Minister at least every five years (Art. 14 (5)). Their results have to be published in the performance report and are to be considered in the performance agreements (Art. 13 (2), (4), 14 (8)).

\section{IId) Financial statement}

The rectorate shall submit an annual financial statement together with the auditor's report and other information such as the opening balance sheet (Art. 20 (6(2)). (Interestingly, it is mentioned independently from paragraphs that contain regulations on the financial statement). The financial statement has to be based on the regulations of the first chapter of the third book of the Commercial Code and further chapters may also be voluntarily applied (Art. 16 (2)). Furthermore the Federal Minister has enacted an order with detailed regulations, the Rechnungsabschluss-Verordnung. While all other reports are only audited according to guidelines of the University Council, the financial statement has to be additionally audited by a registered auditor, independent of the university (Art. 16 (4)) as well as by the Federal Audit Office (Art. 15 (6)). It can be assumed that the Federal Audit Office will not audit regularly and will focus on the efficient, economic, and expedient management as demanded in Art. 2 (12). 
Michaela Schaffhauser-Linzatti

Reporting Systems in Public Administration

\section{III) External reports}

The external reports are addressed to specific stakeholders. In general, they are not subject to formal requirements.

\section{Illa) University report}

The Minister "shall submit to the National Council triennial reports on the universities' previous development and future strategy based on the university performance reports. Such ministerial reports shall contain discussion of the advancement of junior academics, developments with regard to university staffing and students' "situation". The concentration on staffing seems necessary due to otherwise missing information instruments (Seboek 2002, 48; Art. 11 RV). The university report thus represents a summary of the university's performance and provides a basis for a future national university policy.

\section{IIlb) Report of the University Council}

The University Council is obliged to report on "serious breaches of the law by the university governing bodies or on threats of serious financial loss" (Art. 21 (1(12))).

\section{The university intellectual capital statement}

In general intellectual capital statements evaluate and visualise intangible assets and knowledge-based processes not being presented in traditional accounting systems. As a new scientific and managerial instrument, however, targets, terminology and definitions as well as approaches have not been standardised so far (for a detailed discussion see Schaffhauser-Linzatti 2003). One of the most successful approaches has been developed by Austrian Research Centers Seibersdorf (ARC), a public-private research institution with about 600 employees in five departments. First, it derives knowledge objectives from the comprehensive business objectives and strategies and discusses them verbally by narratives. Based on the knowledge objectives it then identifies value-adding potentials (human, structural, and relationship capital) and core processes (basic and contract research) which influence financial and non-financial outputs and outcomes and vice versa presented by qualitative and quantitative indicators. The ARC approach has been adapted, among others, by DLR (2001) and served as a model for the UG 2002 (Leitner at al. 2001).

For universities knowledge or similar intellectual capital is the most relevant production factor and thus should be transparent (Art. 12 (11) RV; Maul/Menninger 2000; Österreichische Rektorenkonferenz 2003). Externally, the university 
intellectual capital statement shall represent a possibility to publicly account for the use of tax money and to publish the university's performance. Internally, it shall deliver information for management and control. World-wide, Austria is the first country to establish an intellectual capital statement by law. In doing so it takes the lead in publishing such information and becomes a standard-setter. The law itself only defines the tasks and the framework of the intellectual capital statement. For the detailed design it refers to the order of the Federal Ministry, which has now been elaborated in cooperation with experts and the universities concerned ${ }^{2}$ and shall become effective on 1 January 2005.

Art. 13 (6) demands the presentation in itemised form of

1. the university's activities, social activities, and self-imposed objectives and strategies

2. intellectual capital, broken down into human, structural and relationship capital

3. the processes set out in the performance agreement, including their outputs and impacts.

Human capital is defined as the knowledge of the academic and nonacademic staff that is relevant to perform all university tasks, structural capital as non-personal equipment, and relationship capital as networks of social relations that support university performances and help acquire knowledge from outside the university (Art. 12 (11) RV).

The draft intellectual capital statement described below is still under discussion, but seems to be very close to the final version. It will be structured into i) a performance spectrum and objectives, ii) intellectual capital, iii) performance processes according to the performance agreements, iv) output and outcomes, and v) résumé.

\section{I) Performance spectrum and objectives}

The university first presents its performance spectrum and specificities in a narrative form. This is followed by matrix containing its objectives, the actual status of their achievement, their target benchmarks, the previous allocation of resources to reach each objective, and a verbal interpretation.

2 The author of this article is part of the ministerial working group and is hence involved in the discussion and implementation of the regulations discussed here. 
Michaela Schaffhauser-Linzatti

\section{Reporting Systems in Public Administration}

\section{II) Intellectual capital}

The intellectual capital is structured into human, structural and relationship capital. For each category, an mandatory set of ratios is expanded on by specific sets for defined fields of studies and research, e.g., medicine or arts. Further ratios may be added voluntarily. A verbal interpretation enables the evaluation of the ratios and their embedding into the university's strategy.

Examples: human capital: number of academic staff; structural capital: available square metres; relationship capital: partnerships with other universities.

\section{III) Performance processes according to the performance agreements, and IV) Output and outcomes}

Both sections contain mandatory and voluntary ratios to be applied generally and for defined fields of studies and research. They are further structured into 1) teaching, 2) research/arts, 3) others. Again, a verbal interpretation enables the evaluation of the ratios and their embedding into the university's strategy.

Examples: performance processes, teaching: number of students/field of study; performance processes, research: number of research projects; output teaching: number of alumni/field of study; output research: granted licences/field of research; output others: activities of the library; outcome teaching: starting salary of alumni.

\section{V) Résumé}

The résumé is a summary, final evaluation and interpretation of the university's performance with respect to the initially stated objectives. It has to contain the development plan of the university.

The introduction of the intellectual capital statement is an important step towards a future-oriented university reporting system. For the first time, the intellectual capital and core processes of universities are evaluated and visualised. However, the approach under discussion is not yet fully developed. Still, 1) contradictory targets and 2) the underlying model have to undergo a critical revision.

\section{1) Contradictory targets}

The contradictory targets that the intellectual capital statement shall fulfil evoke conflicts - most of all standardised versus individual ratios, comprehensive versus low level of information, and ministerial control of the universities including sanctions versus self-governance of each university without ministerial sanctions - that cannot be resolved separately.

Within the universities one important target of the intellectual capital statement is its application as an internal management system. It will lead to shifts in the university's emphasis and to a reallocation of inner-university resources 


\section{Michaela Schaffhauser-Linzatti \\ Reporting Systems in Public Administration}

(Titscher 2004 b, 264) by reflecting more on its own structures and communication and decision processes than before the UG 2002 was introduced (Frackmann 1997, 218, Kautz 1999, 9). Performance may only increase, however, if the results of the intellectual capital statement are linked to adequate incentives and sanctions (Weinert 2001, 4).

Above all, the differing objectives of the Federal Ministry and the universities cause principle-agent conflicts. The Federal Ministry is no longer the supreme authority of the universities that can now act autonomously (Höllinger/Titscher, 2004), however it is still the monitoring principle. As representative of the owners and controlling body it must call the universities to account for their performances (Frankl 1996, 48) and be responsible for quality assurance (Müller-Böling 1997, 88). The intellectual statement that is primarily addressed to the Federal Ministry shall serve as such a statistical information system. It will be the core part of the ministerial data warehouse (Titscher 2004 a, 84, 97, 121) and shall therefore include comprehensive, standardised and comparable information, whereas the universities as agents will try to exploit their informational head start. Consequently, the Federal Ministry must care for data validity and reliability.

\section{2) Underlying model}

As for any intellectual capital statement, the quality - and furthermore the usefulness and acceptance - of the university intellectual capital statement approach depends on a) the structure of the model and b) the applied indicators.

a) Structure of the model

First, the university intellectual capital statement is based on knowledge objectives, general objectives and strategies analogous to the ARC approach. So far it has not been possible to comprehensively define such knowledge objectives, general objectives, and strategies for Austrian universities (bmwf, Altrichter/Schratz/Pechar 1997, 17). Even if they existed, they could not be applied to a general intellectual capital statement, as each university is now permitted to define its own knowledge objectives, general objectives and strategies autonomously, which automatically stands against the targeted uniform model for all universities.

Further, the model includes intellectual capital, performance processes, and outputs and outcomes. While intellectual capital can be related to a university's input and outputs and outcomes to outputs, performance processes as a third category cannot be clearly demarcated from input or output measures (Biedermann 2004, 255), which is necessary to determine efficiency and effectiveness. (For the measurement of efficiency in German universities see Fandel (2003)). Input ratios are value-adding potentials, output ratios results. Due to the complexity of input oriented university control (Kautz 1999, 9), the Federal Ministry will concentrate on output related mechanisms (Titscher 2004 b, 84). The inclusion of 


\section{Michaela Schaffhauser-Linzatti \\ Reporting Systems in Public Administration}

processes in such mechanisms is not resolved. Furthermore it is nearly impossible to define processes in academic performance. If real processes can be defined, process evaluation demands a steady control, which evokes high efforts, motivation of the evaluated and evaluating persons, and a high subjective component (Kautz 1999, 21).

\section{b) Applied indicators}

The university intellectual capital statement belongs to the non-monetary, indicator-based approaches. The choice of the applied indicators mainly faces up to three problems. Firstly, indicators are generally defined as "empirical, quantitative or qualitative data that point to an institution's goal achievement" (van Vught 1997, 61), which implies the existence of objectives, which do not generally exist at the moment.

Secondly, the choice of indicators will predetermine the behaviour of the evaluated persons who tend to orient their behaviour closely towards the indicators on which basis they are being evaluated. Hence, they disregard any other, maybe also relevant aspects (van Vught 1997, 63). Consequently, the set of indicators should perfectly comprise all aspects, which is of course not possible. For the intellectual capital statements developed for profit-oriented enterprises, the indicators are chosen using previous experience and anticipated usefulness. For each period, they are adapted to current requirements. For universities, this indicator selection process cannot be applied (see also Titscher 2004, 80, that all new regulations must be easy to handle). Hence, the choice of well-balanced indicators is one of the most important challenges. Moreover, it will be necessary to define benchmarks as targets in order to measure the absolute quality of the fields of teaching and research (and not merely the relative quality among universities).

Thirdly, intellectual capital statements have to balance relevance and reliability in a similar way to traditional accounting. For this new instrument, however, relevance should dominate, accepting a certain fault tolerance (Weinert 2001, 4). For the choice of indicators it should be taken into consideration that data collection is more time and resource consuming for intellectual capital statements than for traditional accounting (Teichler/Schomburg 1997, 240).

Finally, the definition of fields of study and research should not be based on subjective estimations (Weinert 2001, 22). Leitner et al. (2004) show surprising heterogeneities among fields that up to now have been considered uniform).

Lastly, the published data will be presented in a highly aggregated, not yet defined form due to data protection, which will no longer allow for any significant statistical analyses on university performance. 


\section{Conclusion}

Reporting systems in public entities are not usually placed in the centre of strategic interest. Their importance on internal and external communication, however, should not be underestimated. A thoroughly structured reporting system helps public administration to increase the efficiency of its performance and to transfer its benefits to the broader public in order to justify the application of public funds. However, it is insufficient to use instruments that have been successfully implemented in private firms. It will be necessary to adapt them to the specific needs of public tasks. Thus non-monetary indicators will be used in the main.

Austria may serve as an example of a country implementing a university reporting system. With its forward-looking elements, the university reporting system according to UG 2002 may act as an international archetype. It promotes transparency inside and outside universities and serves as a basis for consequences against internal and external stakeholders. Hence the new reporting system contributes to a reallocation and a more effective and efficient use of mainly - budgetary public resources, and consequently to an increase in the performance of Austrian universities. Nevertheless, already recognised problems first comprise existing overlaps between the individual reports, loopholes that allow for evading consequences or missing regulation regarding monitoring and control of the published, especially non-monetary, information. Second, the reporting period is fixed with the fiscal year. It conflicts with the academic year and causes extensive deferrals as well as the need for parallel records for internal and external use. Furthermore the universities have to bear all implementation costs for the reporting systems, which are negated in the public discussion but will place a significant burden on the universities' accounts. Finally, critics state insurmountable classification and valuation problems due to missing or imprecise definitions. Choosing the intellectual capital statement as an example, two problems arise if the indices follow the suggestions known so far. First, the large number of ratios (and their verbal interpretation) will increase administration to such an extent that it is questionable if the necessary diligence for data acquisition will be applied and if the efforts meet the imposed efficiency criteria. Second, the suitability and benchmarks of ratios have to be discussed in greater detail to prove their necessity and significance. It is necessary to verify if the ratios really reflect the aims of this intellectual capital statement.

\section{Acknowledgement}

I thank Mag. Christine Perle, bm:bwk, and Mag. Alexander Hammer, University of Vienna, very much for valuable information and interesting discussions. 


\section{Michaela Schaffhauser-Linzatti \\ Reporting Systems in Public Administration}

\section{Literature and Sources}

- Austrian Research Centers Seibersdorf (ARC 1999-2002) Wissensbilanzen, http://www.arcs.ac.at/publik/fulltext/wissensbilanz.

- Biedermann, H. (2004) Wissensbilanzierung, in: Höllinger, S./Titscher, St. (eds.) Die österreichische Universitätsreform, Zur Implementierung des Universitätsgesetzes 2002, Vienna, pp. $246-263$.

- Biedermann, H., Graggober, M., Hall, K. (Leoben 2002) Wissensbilanz 2001, Leoben, see also http://www.unileoben.ac.at/institute/iwbw.htm.

- Biedermann, H./Strebl, F. (2004) Leistungsvereinbarung, in: Höllinger, S./Titscher, St. (eds.) Die österreichische Universitätsreform, Zur Implementierung des Universitätsgesetzes 2002, Vienna, pp. $219-245$.

- Deutsche Luft- und Raumfahrt (DRL 2002) Wissensbilanz 2001, Köln.

- Dienstrechts-Novelle 2001 - Universitäten: Bundesgesetzblatt I Nr. 87/2001, ausgegeben am 31. Juli 2001.

- Donau-Universität Krems (DUK 2003) Wissensbilanz 2002, Krems, http://www.donau-uni.ac.at/wissensbilanz.

- Fandel, G. (2003) Zur Leistung nordrhein-westfälischer Universitäten. Gegenüberstellung einer Verteilungslösung und der Effizienzmaße einer Data Envelopment Analysis, in: BackesGellner, U./Schmidtke, C. (eds.) Hochschulökonomie - Analysen interner Steuerungsprobleme und gesamtwirtschaftlicher Effekte, Berlin, pp. $33-50$.

- Frackmann, E. (1997) Leistungsindikatoren - Das Ende der Debatte, in: Altrichter, H./Schratz, M./Pechar H. (eds.) Hochschulen auf dem Prüfstand, Innsbruck, pp. 197 - 222

- Frankl, Ch. K. (1996) Evaluation an Universitäten am Beispiel der Technischen Universität Wien, Vienna.

- Haller, A., Dietrich, R. (2001) Freiwillige Unternehmensberichterstattung in den USA, in: KOR, Zeitschrift für kapitalmarktorientierte Rechnungslegung, 1. Jg., September/Oktober 2001, pp. $206-210$.

- Höllinger, S./Titscher, St. (eds.) Die österreichische Universitätsreform, Zur Implementierung des Universitätsgesetzes 2002, Vienna.

- Imparato, N. (1999) Capital for Our Time. Stanford, California.

- Kautz, Ch. (1999) Evaluierung der Qualität der Lehre, Vienna.

- Leitner, K.-H./Sammer, M./Graggober, M./Schartinger, D./Zielowski, Ch. (2001) Wissensbilanzierung für Universitäten, Auftragsprojekt für das bm:bwk, Sektion VII, Sektion VIII, Endbericht, Seibersdorf.

- Leitner, K.-H./Schaffhauser-Linzatti, M. M./Stowasser, R.Magner, M. (2004) Revealing the true story behind statistical information: a Data Envelopment Approach (DEA) to analyse Austria's universities' research performance, presented on 4th International DEA Symposium, 5-6 September 2004, Birmingham.

- Maul, K.-H./Menninger, J. (2000) Das "Intellectual Property Statement" - eine notwendige Ergänzung des Jahresabschlusses?, in: Der Betrieb. 53. Jg., pp. 529 - 533. 


\section{Michaela Schaffhauser-Linzatti \\ Reporting Systems in Public Administration}

- MERITUM Project (2001) Guidelines for Managing and Reporting on Intangibles, OECD; see also http://www.oecd.org.

- Metz, Th. (1998) Accounting for Organizations, Wie konstituiert das Rechnungswesen Organisationen?, in: Journal für Betriebswirtschaft, Heft 5-6, pp. $253-265$.

- Müller-Böling, D. (1997) Evaluationen zur Rechenschaftslegung oder Qualitätsverbesserung? Eine Bestandsaufnahme der Evaluation an deutschen Hochschule, in: Altrichter, H./Schratz, M./Pechar H. (eds.) Hochschulen auf dem Prüfstand, Innsbruck, pp. 88 - 107.

- Österreichische Rektorenkonferenz (2003) Wissensbilanz: Wissensbilanz - Bilanz des Wissens? Die Wissensbilanz für Universitäten im UG 2002, Vienna, see also http://www.reko.ac.at/upload/wissensbilanz_20030624.pdf.

- Pfaff, D./Bärtl, O. (1998) Externe Rechnungslegung, internes Rechnungswesen und Kapitalmarkt, in: Zeitschrift für betriebswirtschaftliche Forschung. 50. Jg., pp. 757 - 777.

- Promberger, K./Schlager-Weidinger N./Traxl, M. (2003) Verwaltungsmodernisierung durch Enterprise Resource Planning Systeme: Steigerung der Leistungsfähigkeit öffentlicher Verwaltungen durch den Einsatz betriebswirtschaftlicher Standardsoftware, Vienna.

- Regierungsvorlage zum Universitätsgesetz (RV 2002) BGBI. I Nr. 120/2002, 1134 BlgNR 21. GP.

- Setnikar-Cankar, S., Klun, M.: Higher education in Slovenia : Methods to Greather Efficiency in Education Programs. V: Wright, Glen (ur.), Nemec, Juraj (ur.). Public Management in the Central and Eastern European Transition: Concepts and Cases. Bratislava: NISPAcee, 2002, str. 355-362, ilustr. ISBN 80-89013-08-2.

- Setnikar-Cankar, S.: Reforming the Public Sector - the Anti-bureaucracy Programme in Slovenia. in: Montanheiro, Luiz (ur.), Ochojski, Artur (ur.), Kučnik, Florian (ur.). Public and Private Sector Partnership : Sustainable Success. Sheffield: Sheffield Hallam University, 2003, str. 415-429, ilustr. ISBN 1-84387-017-7.

- Setnikar-Cankar, S.: Economic Regulation of the Public Sector in Slovenia-Establishing Effectiveness in: Montanheiro, Luiz (ur.), Public and Private Sector Partnership: Sheffield: Sheffield Hallam University, 2004

- Schaffhauser-Linzatti, M. M. (2000) Ökonomische Konsequenzen der Privatisierung in Österreich, Wiesbaden.

- $\quad$ Schaffhauser-Linzatti, M. M. (2003) Zusammenfassung "Wissensbilanz: Bilanz des Wissens?, Die Wissensbilanz für Universitäten im UG 2002", in: Österreichische Rektorenkonferenz (eds.) Wissensbilanz: Bilanz des Wissens?, Die Wissensbilanz für Universitäten im UG 2002, Vienna, pp. $76-86$

- Schaffhauser-Linzatti, M. M. (2004) Welches Interesse verbindet Sie mit der universitären Wissensbilanz? in: University of Vienna (eds.) Die universitäre Wissensbilanz (working title), to be printed in September 2004, Vienna.

- Seboek, M. (2002) Universitätsgesetz 2002. Gesetzestext und Kommentar Wien.

- Skandia (1994) Visualizing Intellectual Capital, http://www.skandia.com/en/ir/annualreports.shtml. 


\section{Michaela Schaffhauser-Linzatti \\ Reporting Systems in Public Administration}

- Teichler, U./Schomburg H. (1997) Evaluation von Hochschulen auf Basis von Absolventenstudien - Erfahrungen und Überlegungen aus der Bundesrepublik Deutschland, in: Altrichter, H./Schratz, M./Pechar H. (eds.) Hochschulen auf dem Prüfstand, Innsbruck, pp. 236 - 261.

- Titscher, St. (2004 a): Theoretische Grundlagen, Interpretationsvarianten und mögliche Auswirkungen des Universitätsgesetzes. In: Höllinger, S./Titscher, St. (Hg.): Die österreichische Universitätsreform, Zur Implementierung des Universitätsgesetzes 2002. Wien, $73-123$.

- Titscher, St. (2004 b): Profilentwicklung an Österreichs Universitäten. In: Höllinger, S./Titscher, St. (Hg.): Die österreichische Universitätsreform, Zur Implementierung des Universitätsgesetzes 2002. Wien, 264 - 286.

- Universitätsgesetz 2002 (UG 2002) sowie Änderung des Bundesgesetzes über die Organisation der Universitäten und des Bundesgesetzes über die Organisation der Universitäten der Künste, Bundesgesetzblatt I Nr. 120/2002.

- Universitäts-Studienverordnung (UniStEVO 2004) Bildungsdokumentationsverordnung.

- Van Vught, F. (1997) The Humboldtian University Under Pressure. New Forms of Quality Review in Western European Higher Education, in: Altrichter, H./Schratz, M./Pechar, H. (eds.) Hochschulen auf dem Prüfstand, Innsbruck, pp. 48 - 87.

- Verordnung der Bundesministerin für Bildung, Wissenschaft und Kultur über den Rechnungsabschluss der Universitäten (RechnungsabschlussVO) BGBI. 18. Juni, Jg. 2003, Teil II.

- Weinert, F. E. (2001) Die evaluierte Universität, Heidelberg. zwm (2003) Wissensbilanzen: Neue Transparenz für eine Bewertung immaterieller Werte in Hochschulen und F\&E Einrichtungen, December 5, 2003, Vienna.

Michaela Schaffhauser-Linzatti, Assistant Professor at the University of Vienna, School of Business, Economics, and Computer Science, Department of Financial Accounting, guest professor at the Europa University Viadrina, Frankfurt/Oder, Germany, principally researching financial accounting and efficiency in public organisations. 


\section{POVZETEK}

\section{Sistemi poročanja v javni upravi, novi pristopi za avstrijske univerze}

Proračunske zadrege niso značilne samo za države, ki spreminjajo svoje sisteme delovanja in uvajajo tržne zakonitosti. Podatki kažejo, da se je v zadnjih letih pojavil povečan interes za povečanje odgovornosti in hkrati izboljšanje učinkovitosti ter realnejše razdelitve finančnih sredstev tudi $v$ mnogih razvitih državah.

Le-te širijo uvedbo metod merjenja opravljenih storitev $v$ javnem sektorju. $V$ minulem desetletju so menedžerji pridobili obsežno znanje s področja uvajanja reform za merjenja učinkovitosti. Pozornost se je počasi preusmerjala od posebnosti strategij inovativnosti (kaj je merjenje učinkovitosti) k strategijam za uvajanje sprememb (kateri so potrebni koraki). Zagotavljanje ustrezne podpore lastnikov (tudi države) in tehnične sposobnosti so tako postali ključni pogoji za uvajanje reform.

Visokošolsko izobraževanje je eno od zahtevnejših področij, ki dopolnjuje uveljavljene kazalce dejavnosti s kazalci finančne uspešnosti in ekonomike. $\vee$ članku je predstavljen primer uporabe prilagojenega sistema uravnoteženih kazalcev za izbrane univerze $v$ Avstriji. Izpostavljeni so nemonetarni vidiki poročanja in odprta vprašanja določanja ustreznih kazalcev. Praviloma ti sistemi temelje na uporabi in izkušnjah zasebnega sektorja gospodarstva. Seveda ni mogoč neposreden prenos, temveč je treba na pilotskih projektih predhodno opredeliti sistem poročanja in njegove razlike. 